\title{
Deletions in the COL4A5 Collagen Gene in X-linked Alport Syndrome \\ Characterization of the Pathological Transcripts in Nonrenal Cells and Correlation with Disease Expression
}

\author{
Corinne Antignac, * Bertrand Knebelmann, * \\ Marie-Claude Hors-Cayla," Jing Zhou, ${ }^{1}$ Karl Tryggvason, * * Jean-Pierre Grünfeld, * \\ Michel Broyer, ${ }^{\star *}$ and Marie-Claire Gubler* \\ *INSERM U192, "Department of Nephrology, and 'INSERM U12, \#Department of Pediatric Nephrology, Hôpital Necker-Enfants \\ Malades, 75743 Paris, Cedex 15, France; ${ }^{\S}$ Department of Pediatric Nephrology, Hopital de Clocheville, 37000 Tours, France; "Howard \\ Hughes Medical Institute, Yale University School of Medicine, New Haven, Connecticut 06510; and ** Biocenter and Department of \\ Biochemistry, University of Oulu, 90570 Oulu, Finland
}

\begin{abstract}
The type IV collagen $\alpha 5$ chain (COL4A5) gene of 88 unrelated male patients with $\mathrm{X}$-linked Alport syndrome was tested for major gene rearrangements by Southern blot analysis, using COL4A5 cDNA probes. 14 different deletions were detected, providing a $16 \%$ deletion rate in the COL4A5 gene in the patient population. The deletions are dispersed all over the gene with different sizes, ranging from $1 \mathrm{~kb}$ to the complete absence of the gene $(>250 \mathrm{~kb})$ in one patient. In four patients with intragenic deletions, absence of the $\alpha 3$ (IV) chain in the glomerular basement membrane was demonstrated by immunohistochemical studies. This finding supports the hypothesis that abnormalities in the $\alpha 5$ (IV) chain may prevent normal incorporation of the $\alpha 3$ (IV) chain into the glomerular basement membrane. Direct sequencing of cDNA amplified from lymphoblast mRNA of four patients with internal gene deletions, using appropriate combinations of primers amplifying across the predicted boundaries of the deletions, allowed us to determine the effect of the genomic rearrangements on the transcripts and, by inference, on the $\alpha 5$ (IV) chain. Regardless of the extent of deletion and of the putative protein product, the 14 deletions occur in patients with juvenile-type Alport syndrome. (J. Clin. Invest. 1994. 93:1195-1207.) Key words: $\alpha 5$ (IV) collagene chain • COL4A5 mutation • illegitimate transcription
\end{abstract}

\section{Introduction}

Alport syndrome $(\mathrm{AS})^{1}$ is a progressive hereditary nephritis associated with sensorineural hearing loss and often ocular lesions (lenticonus and/or macular lesions) (1). Phenotypic heterogeneity stems from the rate of progression to end-stage renal disease (ESRD), with two predominant clinical types, juve-

Preliminary reports of this work have been published in abstract form (1991. J. Am. Soc. Nephrol. 2:249; 1992. J. Am. Soc. Nephrol. 3:298). Address correspondence to Dr. Corinne Antignac, INSERM U192, Tour Lavoisier, 6ème étage, Hôpital Necker, 75743 Paris Cédex 15, France.

Received for publication 13 September 1993 and in revised form 15 November 1993.

1. Abbreviations used in this paper: AS, Alport syndrome; DMD, Duchenne muscular dystrophy; ESRD, end-stage renal disease; GBM, glomerular basement membrane; NC, noncollagenous.

J. Clin. Invest.

(C) The American Society for Clinical Investigation, Inc. $0021-9738 / 94 / 03 / 1195 / 13 \quad \$ 2.00$

Volume 93, March 1994, 1195-1207 nile-onset ESRD and adult-onset ESRD, and from the association or not with extrarenal symptoms (2). Its mode of inheritance is mainly $\mathrm{X}$-linked dominant with an estimated incidence of $1 / 5,000$. Autosomal recessive and dominant forms have also been reported (3). Characteristic ultrastructural changes of the glomerular basement membrane (GBM) include thickening with splitting of the lamina densa, whereas the GBM may be uniformily thin in some AS patients (4). Furthermore, immunohistochemical studies with antibodies directed against the noncollagenous (NC) domain of type IV collagen showed impaired GBM antigenicity in most AS patients $(4,5)$, suggesting a primary defect in type IV collagen, the major GBM structural component. Type IV collagen has a triple-helical structure composed of three $\alpha$ chains. These $\alpha$ chains contain long Gly-X-Y repeat sequences that form the collagenous domain, interrupted 21-23 times by non collagenous sequences. At the carboxy-terminal end, each $\alpha$ chain has a highly conserved 26-28-kD NC domain, involved in the folding of $\alpha$ chains into the triple helix and in the formation of intermolecular cross-links through cysteine residues. Six different types of $\alpha$ (IV) chains have been described. The $\alpha$ I (IV) and $\alpha 2$ (IV) are found in most basement membranes and are encoded by head-to-head genes located on the long arm of chromosome 13 (6). The $\alpha 3, \alpha 4$, and $\alpha 5$ (IV) chains have a more restricted distribution, mainly in specialized basement membranes of the kidney, ear, and eye $(7,8)$. The genes encoding for the $\alpha 3$ and $\alpha 4$ (IV) chains have been partially cloned and mapped side by side in 2q35-q37 (9). The human COL4A5 gene encoding the $\alpha 5$ (IV) chain has been mapped to Xq22 (10), where linkage analysis has mapped the AS locus (11). Several major gene rearrangements and point mutations in this gene have been found in AS patients (12). No extensive study on a large population of X-linked AS families has yet been performed to assess the frequency and extent of deletions. Very recently a sixth $\alpha(\mathrm{IV})$ chain encoding gene (COL4A6) has been cloned and shown to be located head to head with COL4A5 (13). Data regarding to its involvement in AS are still lacking.

In this article, we report the characterization of major COL $4 A 5$ defects in $88 \mathrm{X}$-linked AS families. We found 14 different deletions, providing a deletion rate of $16 \%$ in the gene in this patient population. Because the mRNA represents the actual template for translation, the nature of a defect at the mRNA level can correlate better with disease severity than does the putative mRNA structure extrapolated from genomic data. Because the expression of the COL4A5 gene is restricted to specific tissues, none of which being readily obtained, we took advantage of the illegitimate transcription of highly tissuespecific genes in easily accessible cells such as lymphocytes (14) 
to characterize pathological $C O L 4 A 5$ transcripts in AS patients.

\section{Methods}

Patients. 88 unrelated male patients have been studied. All had hematuria. In each family, the pedigree was compatible with an X-linked transmission, with no male-to-male transmission and a more severe disease in males. 84 patients had classical AS. According to Flinter et al. (15), three of the following four diagnostic criteria are required for AS: positive family history of hematuria, with or without progression to ESRD, sensorineural deafness in the proband or in an affected member of the family, typical ocular changes (lenticonus and/or macular changes), and GBM ultrastructural changes. In addition, we took into account a fifth criterion, absence by immunohistochemistry of the $\alpha 3$ and $\alpha 4$ chains of type IV collagen in the GBM, which, in our experience, is a specific marker for AS (4). At least three of these criteria were present in 53 patients. We also considered as affected 31 patients who fulfilled only two criteria: 24 had typical progressive hereditary nephritis with hearing loss, but they did not undergo renal biopsy; the others were young children without extrarenal symptoms at the time of renal biopsy. Analysis of the rate of progression to ESRD, when possible, allowed the distinction between juvenile type ( 57 cases, with an average age at ESRD of $20 \mathrm{yr}$ ) and adult type ( 10 cases, with an average age at ESRD of $42 \mathrm{yr}$ ). One patient belongs to a large family with an intermediate type of AS, characterized by an average age of ESRD of 31 $\mathrm{yr}$, ranging from 14 to 41.16 patients aged 5-15 yr were unclassified because of their young age and of the absence of other affected males in their family. However, 15 of these 16 patients developed hematuria and proteinuria before the age of $6 \mathrm{yr}$, with early occurrence of deafness in five of them and are probably affected with the juvenile type of AS. One patient had megathrombocytopenia and three had diffuse esophageal leiomyomatosis.

Four patients had progressive hereditary nephritis without any extrarenal symptoms.

Transplantation has been performed in the proband and/or in affected male relatives of 44 kindreds. One patient with juvenile AS developed anti-GBM antibodies and crescentic glomerulonephritis 5 mo after transplantation, leading to the loss of the graft. No other affected patient in his family has been transplanted.

Immunohistochemical study. Indirect immunofluorescence study of the glomerular distribution of the $\alpha 3$ and $\alpha 4$ chains of type IV collagen, and of the $\alpha$ (IV) chain (control), was performed in 30 AS patients. Eight normal kidneys not used for transplantation, and 45 renal biopsy specimens of patients presenting various types of acquired glomerulopathies, were tested as controls.

The monoclonal anti- $\alpha 3$ (IV) antibody, mAb 17, a gift from J. Wieslander (University of Lund, Sweden), recognizes the very anionic 28-kD monomer extracted from GBM collagen, and corresponding to the NCl domain of the $\alpha 3$ (IV) chain. The monoclonal anti- $\alpha 4$ anti- body, mAb 85, a gift from M. Kleppel (University of Minnesota), recognizes the more neutral $28-\mathrm{kD}$ monomer corresponding to the $\mathrm{NCl}$ domain of the $\alpha 4$ (IV) chain. The NC1 specificities of these antibodies have been previously established $(16,17)$. The monoclonal anti- $\alpha$ I IV) antibody is directed against the $\mathrm{NCl}$ domain of the $\alpha 1$ (IV) chain (Wieslab, Lund, Sweden). Affinity-purified FITC-conjugated sheep anti-mouse IgG were obtained from Silenus (Hawthorn, Victoria, Australia).

Serial acetone-fixed, cryostate sections of snap-frozen kidney tissue were stained with primary antibodies followed by FITC-conjugated secondary antibodies. Control sections, directly incubated with the secondary antibodies, were negative. Positive labeling of renal basement membranes with the anti- $\alpha$ l(IV) antibody was observed in AS patients as in controls. The $\alpha 3$ and $\alpha 4$ chains of type IV collagen were normally present in the GBM and the distal tubular basement membrane of controls and of eight AS patients. Conversely, no labeling could be detected in 22 AS patients.

Southern blotting analysis. Genomic DNA was isolated from peripheral blood lymphocytes, digested using four enzymes (PstI, EcoRI, MspI, and TaqI), and hybridized successively with a set of cDNA probes spanning the entire COL4A5 cDNA. The cDNA probes included respectively, from the $5^{\prime}$ to the $3^{\prime}$ end, the following clones: JZ4, HT 14-1, HT 14-2, and HT14-3, which contain the coding sequence for the $5^{\prime}$ untranslated region and the amino acid residues 1-911, and a pool of inserts of the 3' end clones (PL31-MD6-Pc4b) coding for residues 912-1685 and the $3^{\prime}$ end untranslated region (10). In order to characterize the extent of the deletions, some patient DNAs were hybridized with genomic probes: an EcoRI genomic fragment in pUC18, LA226-E1, containing the first exon of both COL4A5 and COL4A6, the intergenic region, $140 \mathrm{bp}$ of genomic sequences downstream COL4A6 exon 1 and $0.4 \mathrm{~kb}$ of genomic sequences downstream COL4A5 exon $1(13,18)$, and the genomic phage vector clones MG3, F7, F8 (19). Southern blotting and hybridization were performed as described previously (18).

$P C R$. For analyzing mutations in some individuals, exon-specific PCR primers were made based on the published sequence ( 19 ; see also Table 1). PCR reactions, using $50 \mathrm{ng}$ of patient DNA, were performed as described below for the nested cDNA-PCR.

$R N A$ preparation and reverse transcription. Total cellular RNA was extracted from EBV-immortalized lymphoblastoid cell lines or PBL as described (20). The cDNA was synthetized by random priming using hexanucleotide primers as template for the reverse transcriptase. Samples $(500 \mathrm{ng})$ of total lymphoblast or PBL RNA in water were incubated at $65^{\circ} \mathrm{C}$ for $10 \mathrm{~min}$, topped with $50 \mu \mathrm{l}$ of light paraffin, and then snap-chilled on ice. The sample was then increased to a total volume of $40 \mu \mathrm{l}$ with a premix containing $1.25 \mathrm{mM}$ of each deoxynucleotide triphosphate, $4 \mu \mathrm{l} 100$ of DTT, $200 \mathrm{U}$ Moloney murine leukemia virus reverse transcriptase (Promega Biotec, Madison, WI), 40 U RNAsin (Promega Biotec), $200 \mathrm{pmol}$ of random hexamer primers (pd[N6]; Pharmacia, Uppsala, Sweden), and $5 \mu \mathrm{l}$ of $5 \times$ buffer ( $250 \mathrm{mM}$ Tris-

Table I. Sequences of Oligonucleotides Used for PCR Amplification

\begin{tabular}{|c|c|c|c|}
\hline \multicolumn{3}{|c|}{ Genomic DNA amplification } & cDNA amplification \\
\hline $38 \mathrm{~F}$ & TCATTTTTAAATTGAGCTCTTTAC & $\mathrm{JC1}$ & TCAATTGGTTAGAGCCAGCC (137) \\
\hline $38 \mathrm{R}$ & AACAGCAAACTGTTATTTTTCATG & $\mathrm{JC} 2$ & TCCACCACCTACAGGACCAG (3665) \\
\hline $42 \mathrm{~F}$ & ATGTCGTCATTTGCTGTGGATTA & $\mathrm{JC3}$ & AACTGCGTGGAGTCAGCCTG (208) \\
\hline $42 R$ & CATCAGATATCTACTTCCATTTCC & $\mathrm{JC} 4$ & GTTCCCAGGAGGGCCACTAA (3626) \\
\hline $45 \mathrm{~F}$ & CCCTTCAAATTTGTGTGTTTTGTC & SL1 & TCTGGAGTTCCTGGACAACC (3342) \\
\hline \multirow[t]{5}{*}{$45 R$} & GATAATAAAGATGATCTGCATTGG & SL2 & ATTCCCTGGAGTCCTGGTG (4133) \\
\hline & & SL3 & CCTGGTATTTCAAGCATTGG (3424) \\
\hline & & SL4 & AATACCTCCATTTCCAGGGA (4043) \\
\hline & & B2 & AGGAGGACCCATAACTGCAGC (1391) \\
\hline & & B4 & TAGTTATACCAGTCCCAGGTC (1265) \\
\hline
\end{tabular}

Primer sequences are presented $5^{\prime}$ to $3^{\prime}$. Numbers after each cDNA primer refer to the location of the first $5^{\prime}$ base according to Zhou et al. (35). 
$\mathrm{HCl}, \mathrm{pH} 8.3,375 \mathrm{mM} \mathrm{KCl}$, and $15 \mathrm{mM} \mathrm{MgCl}_{2}$ ). Reactions were incubated at $42^{\circ} \mathrm{C}$ for $60 \mathrm{~min}$ before the reverse transcriptase was inactivated at $95^{\circ} \mathrm{C}$ for $5 \mathrm{~min}$.

Nested PCR and direct DNA sequencing. $10 \mu \mathrm{l}$ (out of 40 ) of the reverse transcription reactions was used for each nested PCR reaction. A 40- $\mu \mathrm{l}$ mixture containing $4 \mu \mathrm{l}$ of $10 \times \mathrm{PCR}$ buffer ( $100 \mathrm{mM}$ Tris- $\mathrm{HCl}$, pH 8.3, $500 \mathrm{mM} \mathrm{KCl}, 15 \mathrm{mM} \mathrm{MgCl}$ ), $1 \mathrm{U}$ Taq polymerase, $25 \mathrm{pmol}$ forward and reverse primer (see Table II) was added to $10 \mu \mathrm{l}$ of the reverse transcription reaction. $30-40$ cycles of PCR $\left(95^{\circ} \mathrm{C}\right.$ for $30 \mathrm{~s}$, annealing temperature for $1 \mathrm{~min}, 72^{\circ} \mathrm{C}$ for $2 \mathrm{~min}$ ) were performed on each sample, followed by an incubation at $72^{\circ} \mathrm{C}$ for $5 \mathrm{~min} .2 \mu \mathrm{l}$ of the
PCR product was added to a $30-\mu \mathrm{l}$ mixture containing $3 \mu \mathrm{l}$ of $10 \times \mathrm{PCR}$ buffer, $3 \mu \mathrm{l} 25 \mathrm{mM}$ dNTPs, $15 \mathrm{pmol}$ forward and reverse nested primers, and $1 \mathrm{U}$ Taq polymerase. PCR was repeated as above for 30 cycles. Sequencing reactions were performed as described (21).

\section{Results}

\section{Extent of the deletions}

Southern blot screening from 88 patients with AS revealed 15 patients with different abnormal restriction patterns (Fig. 1).

A

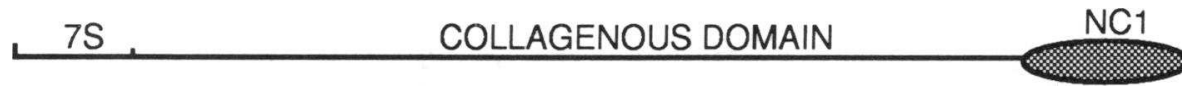

$\alpha 5$ (IV) CHAIN

B

CDNAPROBES

\begin{tabular}{rrr}
$J Z-4 A$ & $H T-14.2, H T-14.3$ \\
\hline$H$
\end{tabular}

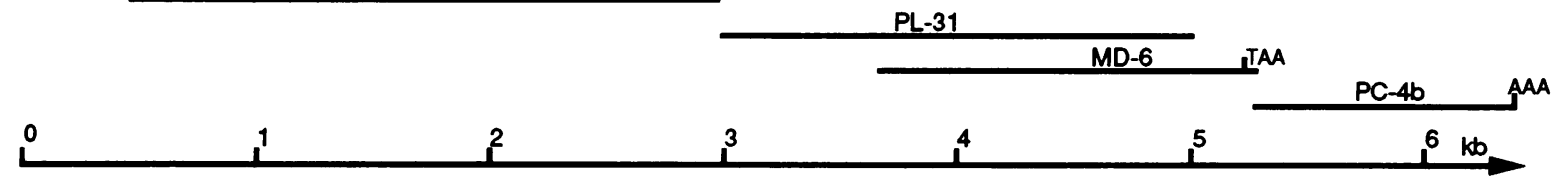

C

\section{DELETIONS}

5

3'

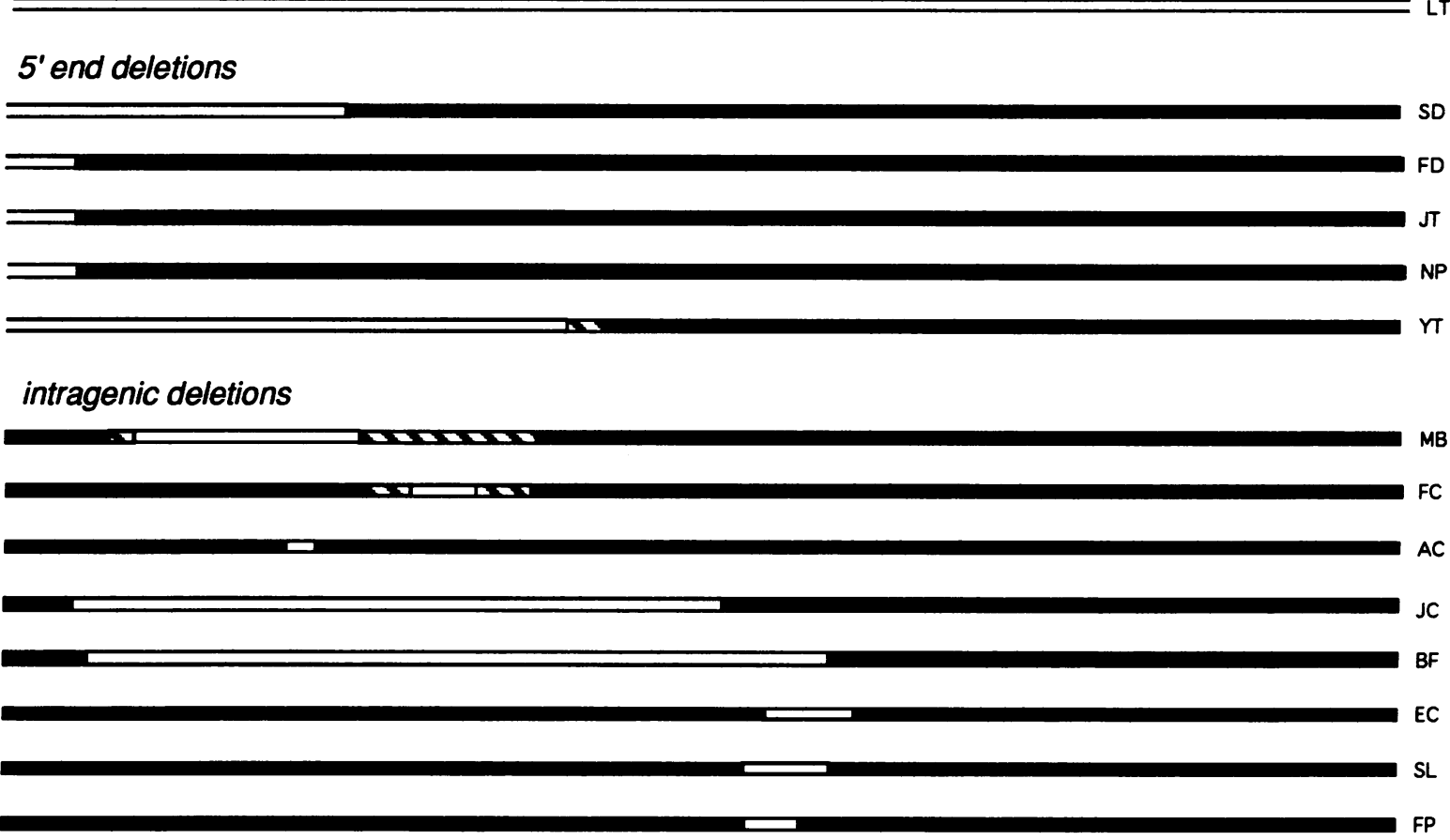

SINGLEBASE MUTATION

5

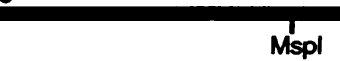

Gly $325 \longrightarrow$ Arg

Figure 1. Schematic diagram of the different mutations in COL4A5 cDNA in patients with AS. $(A)$ Schematic representation of the $\alpha 5$ (IV) chain. $\mathrm{NCl}$ denotes the noncollagenous carboxy-terminal domain. $(B)$ Location of the seven cDNA probes used for Southern blot experiments. (C) Schematic representation of the 14 deletions in COL4A5 cDNA. Black bars denote the normal gene, white bars denote the deleted region of the gene, and hatched bars denote the boundaries of the deletions that are not yet precisely defined. At the bottom is shown the position of the single-base mutation suppressing an MspI site. 


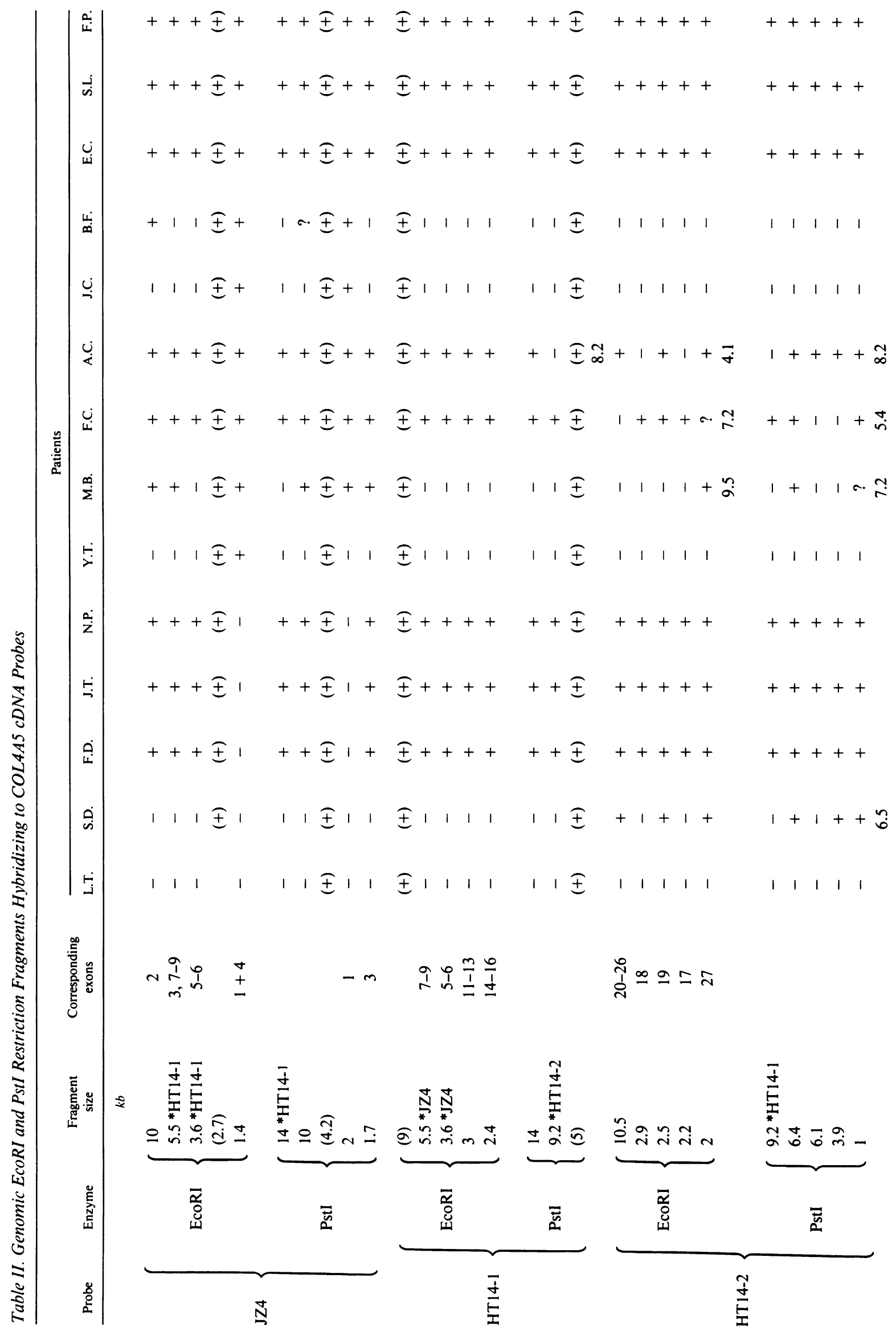




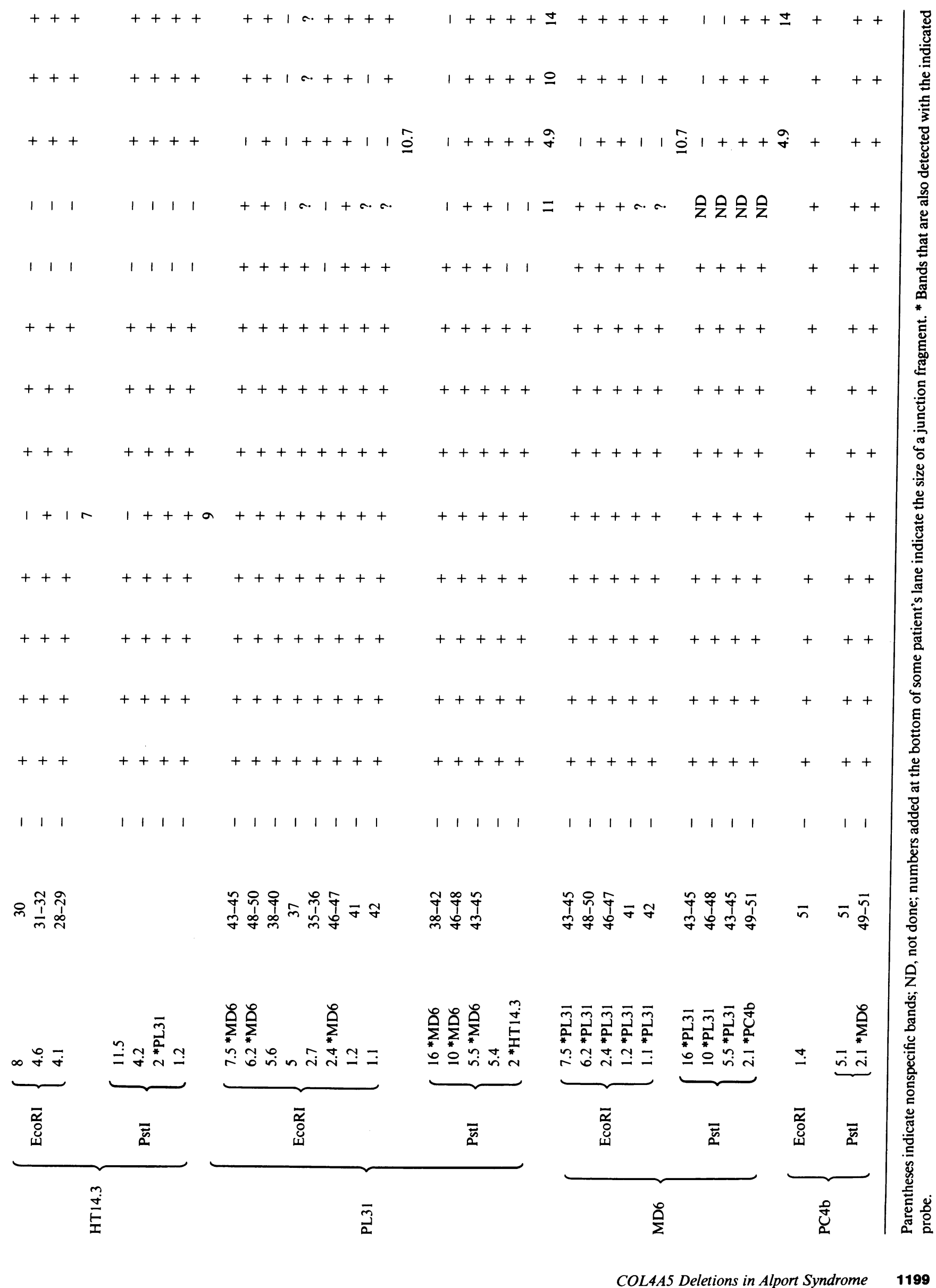


The sizes of the bands observed with the seven cDNA probes with PstI and EcoRI are indicated in Table II.

In one case (B.D.), a loss of an MspI site was discovered with probes HT14-1 and HT14-2. With MspI, the HT14-1 probe showed the absence of the 5.3-kb band replaced by a 12.7-kb band, while both the 7.4 and $5.3 \mathrm{~kb}$ were lacking with the HT14-2 probe, replaced by a $12.7-\mathrm{kb}$ band. This abnormal pattern was shown to be the consequence of a point mutation (21).

14 patient DNAs cleaved with the four enzymes were shown to lack normal bands hybridizing to one or several COL4A5 cDNA probes, suggesting major rearrangements of the COL $4 A 5$ gene in these patients. Six of them (S.D., F.D., J.T., B.F., F.C., F.P.) were partially described elsewhere $(18,22)$.

Complete deletion. In patient L.T. we observed a complete absence of hybridization of all the cDNA probes and of the LA226-E1 and MG3 genomic probes as well. This pattern indicates a complete deletion of the COL $4 A 5$ gene extending at least from $0.7 \mathrm{~kb}$ upstream of the $5^{\prime}$ end of the cDNA and $10 \mathrm{~kb}$ downstream of the $3^{\prime}$ end.

5 ' end deletions. Five patients (S.D., F.D., J.T., N.P., Y.T.) lacked the 2-kb PstI and 1.4-kb EcoRI restriction fragments hybridizing to the JZ4 probe and including exon 1 (13). Furthermore, the EcoRI Southern blots of these five patients exhibited no signal with the LA226-E1 genomic probe, demonstrating major deletions of the $5^{\prime}$ part of the COL4A5 gene with a $5^{\prime}$ breakpoint located upstream of the $C O L 4 A 5$ cDNA. Patients F.D., J.T., and N.P. had no other abnormality with all the cDNA probes, meaning that the deletion at its $3^{\prime}$ end encompasses only the first COL4A5 exon. For patients S.D. and Y.T., the patterns observed with the different probes show that the deletion extends to exon 18 for patient S.D., and that the $3^{\prime}$ deletion breakpoint lies in the region detected by the HT14-3 probe around exon 30 for patient Y.T.

Intragenic deletions. Eight patients (M.B., F.C., A.C., J.C., B.F., E.C., S.L., F.P.) lacked combination of restriction fragments hybridizing to one or several cDNA probes, suggesting completely intragenic $C O L 4 A 5$ deletions. The patterns of hybridization observed with the different $C O L 4 A 5$ CDNA probes, and with the genomic probes $\mathrm{F} 7$ and F8 in patients J.C., S.L., and F.P., as well as PCR amplification of genomic DNA for exons 38, 42, and 45 (see Table I for primers' sequences), allowed us to precize to some extent the size of the deletions (Table II and Fig. 2).

Thus, the M.B. deletion encompasses exon 4 or 5 at the $5^{\prime}$ end, to exon 26 at the most, at the $3^{\prime}$ end. Patient F.C. has a genomic deletion of roughly $5 \mathrm{~kb}$ in the region covered by the HT14-2 probe, including, at the most, exons 20-26. Patient A.C. showed an abnormal pattern only with the HT14-1 and HT 14-2 probes. The PstI, EcoRI, and MspI patterns suggest that the patient has a deletion of $1 \mathrm{~kb}$ encompassing the MspI site located in exon 17. Patient J.C. exhibits a major deletion in the COL $4 A 5$ gene, from exon 2 (inclusive) to exon 37. From the Southern blotting analysis alone, it is not possible to conclude whether or not exon 37 is included in the deletion. For patient B.F., the deletion extents from exon 3 (inclusive) to exon 41. Patients E.C., S.L., and F.P. had an abnormal pattern only with the PL31 and MD6 probes. The data suggest that patient E.C. has a deletion of $11 \mathrm{~kb}$, involving exon 39 through 42 and patient S.L. has a deletion involving exons 38 through 41 , with or without exon 37. Patient F.P. should have a deletion of $\sim 2 \mathrm{~kb}$ involving, at the most, exons 38 through 40 .

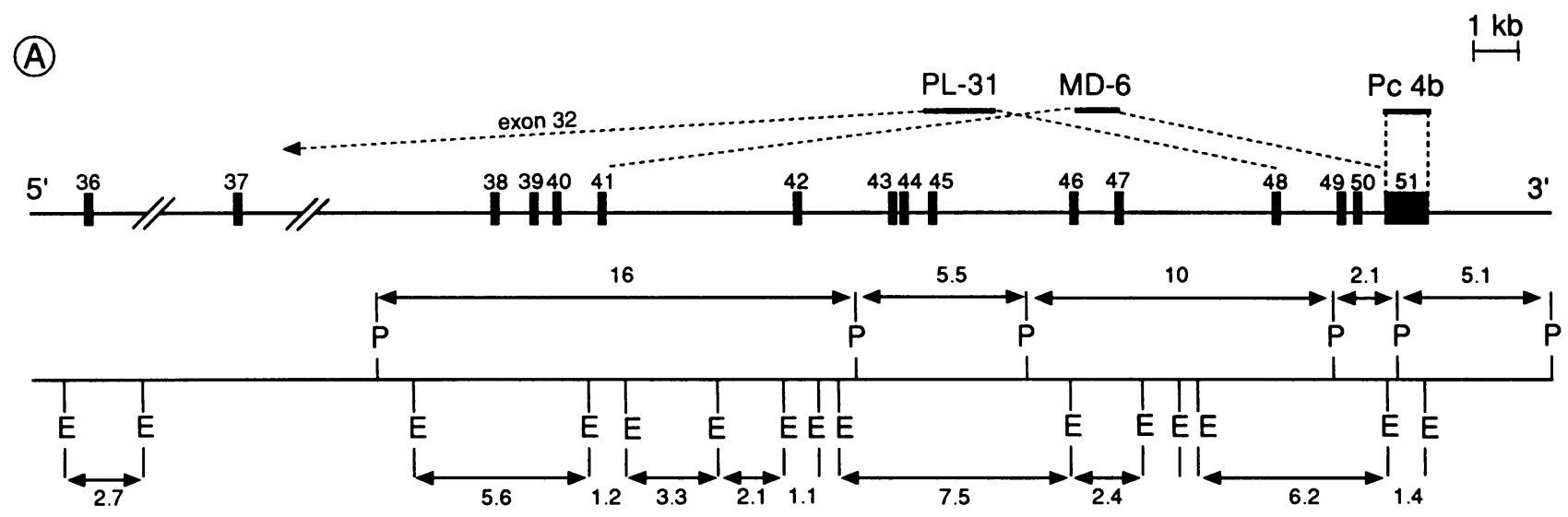

(B)

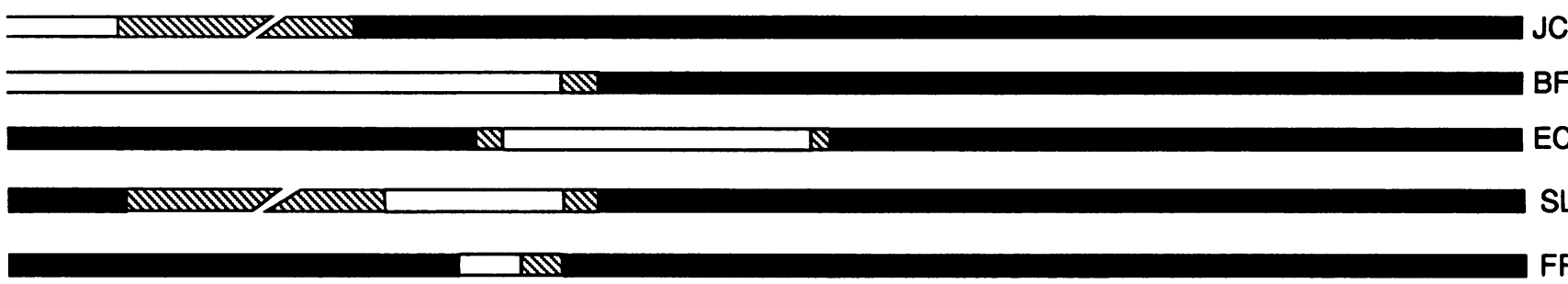

Figure 2. $(A)$ Map of the location of the $3^{\prime}$ cDNAs clones used in this study relative to EcoRI $(E)$ and PstI $(P)$ genomic map of the region $(23$, 25 ). Exon/intron structure is based on Kleppel et al. (16). (B) Alignment of the deletions involving this region of the COL4A5 gene of five patients described in the text. 
Putative protein product and characterization of the truncated transcripts of the COL4A5 gene in nonrenal cells from $A S$ patients

The putative protein product could have been deduced from the results of Southern blotting and PCR amplification of genomic DNA in two patients with intragenic deletions (B.F. and E.C.). In these cases, the deletion would result in a frameshift mRNA and lead to a very short protein containing only the 7S domain and 77 amino acids of the amino-terminal part of the collagenous domain in the former, and to a truncated protein missing the entire noncollagenous domain and 305 amino acids of the carboxy-terminal part of the collagenous domain in the latter.

On the basis of the suggested rearrangements in the COL4A5 gene of four other patients (J.C., A.C., S.L., and F.P.), we have screened by PCR amplification different portions of the COL4A5 mRNA from cultured lymphoblastoid cell lines or PBL using primers flanking the suspected deleted exons (see Table I for the sequence of the primers). Fig. 3 shows the results of the cDNA-PCR amplification and Fig. 4 the sequence of the pathological transcripts. Amplification of PBL RNA from patient J.C. with primers JC3 and JC4 (Fig. 3 $B$, lane 1) resulted in a 243-bp fragment, compared to an unamplified expected fragment of $3,570 \mathrm{bp}$. Sequence analysis confirmed splicing of exon 1 to exon 37, leading to a dramatically shortened in-frame transcript. The protein product would lack two-thirds of the amino-terminal part of the collagenous domain. Patient A.C. showed a 1,005-bp product instead of the normal 1,059 bp with primers JC3 and B4 (Fig. $3 \mathrm{~B}$, lanes 2 and 3). Sequence analysis showed absence of exon 17 (Fig. 4), maintaining an open reading frame. The truncated protein would lack 18 amino acids, from Gly-313 to Lys-330, between interruptions IV and V of the collagenous domain. The Gly-X$Y$ sequence characteristic of the collagenous domain would be preserved. Amplification of patient S.L. RNA with primers SL3 and SL4 (Fig. $3 A$ ) yielded a PCR product of 222 bp (Fig. 3 $B$, lane 4) vs. 639 bp in the control (lane 5), consistent with the loss of exons 38-41. Sequence analysis (Fig. 4) confirmed that exons 37 and 42 were precisely abutted. The translation of this pathological in-frame transcript would result in a loss of 139

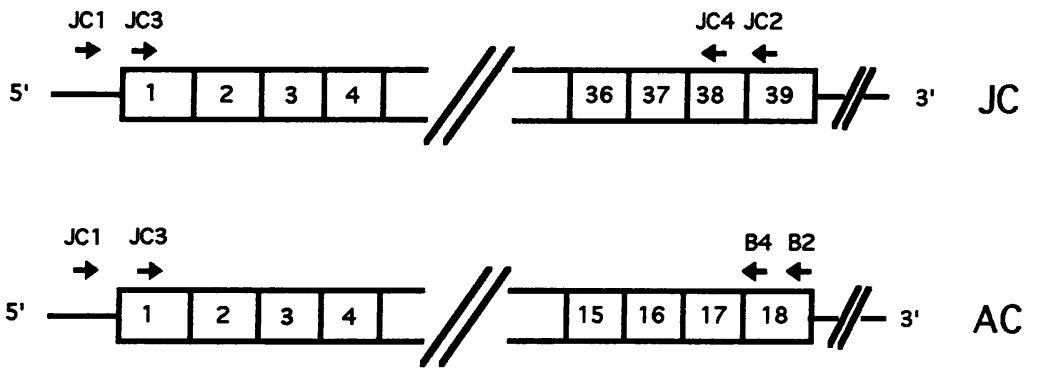

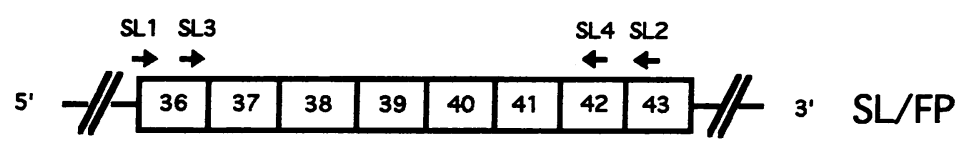

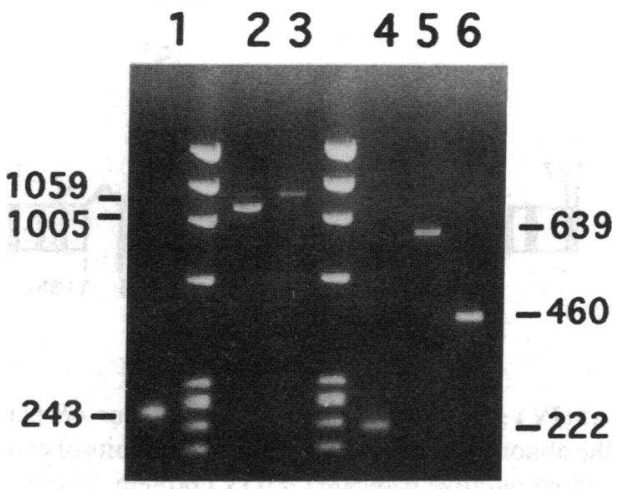

Figure 3. Characterization of the truncated transcripts of the COL4A5 gene in lymphocytes from four patients with intragenic deletion. $(A)$ Schematic diagram of $\alpha 5$ (IV) mRNA, showing positions of the four nested PCR reactions for patients J.C. (top), A.C. (middle), and S.L. and F.P. (bottom). Sequences and exact locations of the primers are given in Table I. (B) Amplification products from lymphocyte RNA. Lane $1, \alpha 5$ transcript of patient J.C. with primers JC3 and JC4 is $243 \mathrm{bp}$ instead of a normal expected 3570 bp. Lane 2, patient A.C. transcript amplified with primers JC3 and B4 is $1,005 \mathrm{bp}$ compared to the normal $1,059 \mathrm{bp}$ in lane 3 . Amplification with SL3 and SL4 shows that patient S.L. transcript is $222 \mathrm{bp}$ in lane 4 , and patient F.P. has a 460 -bp transcript in lane 6 , compared to a control of 639 bp in lane 5 . 


\section{A T G C $\quad 3^{\prime} \quad 5^{\prime}$}
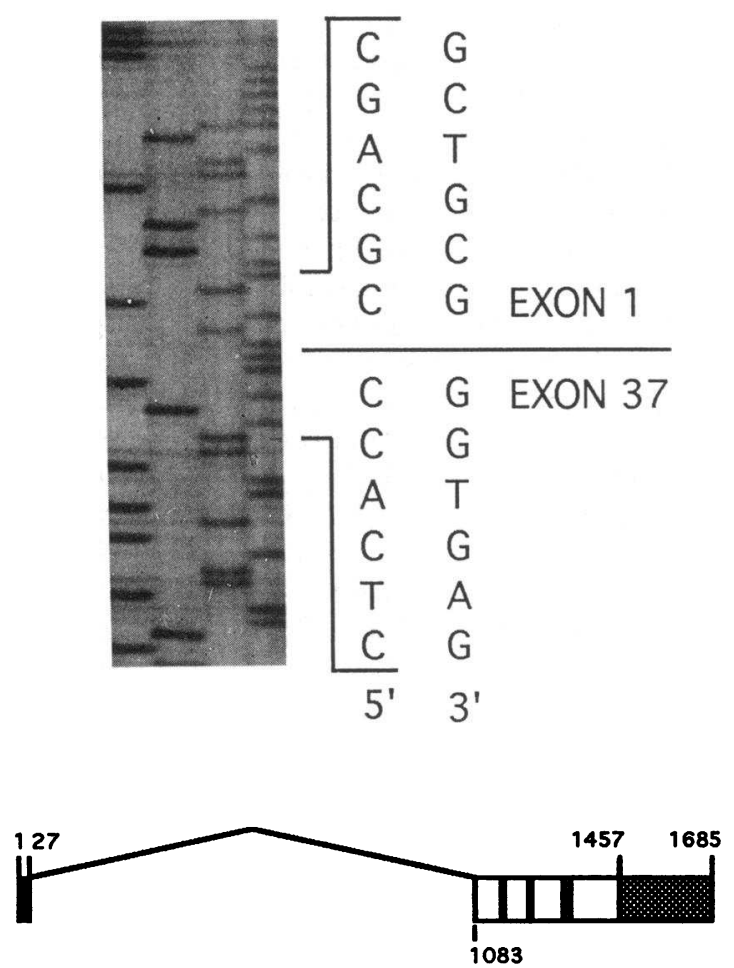

JC
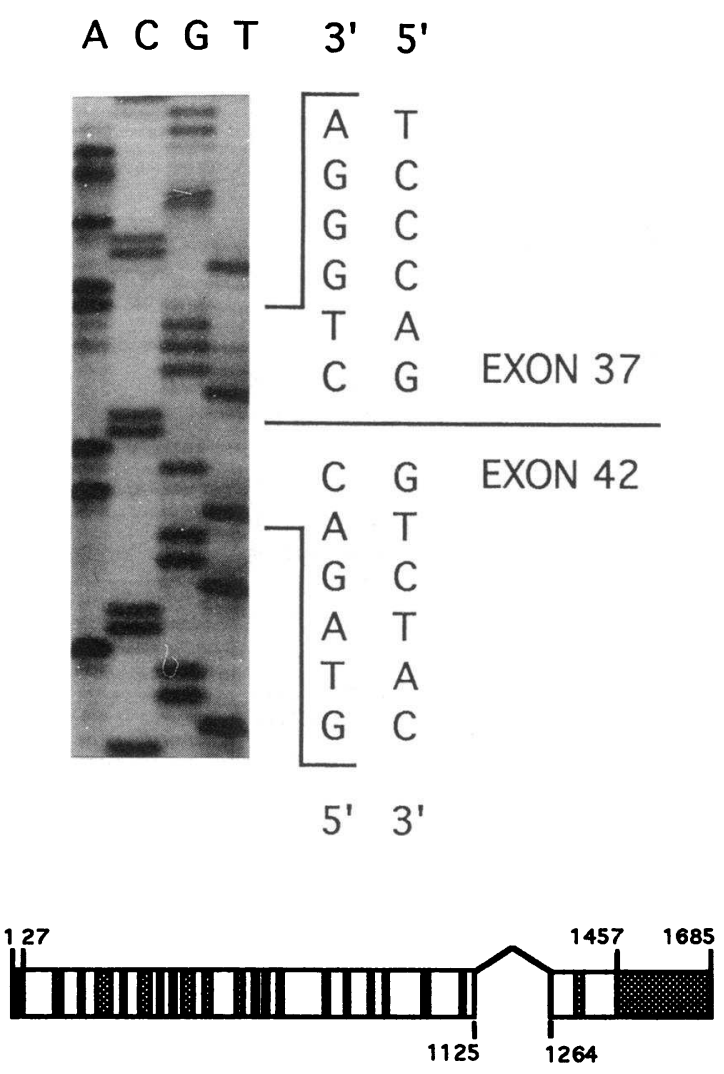

SL
A C G T $3^{\prime} 5^{\prime}$

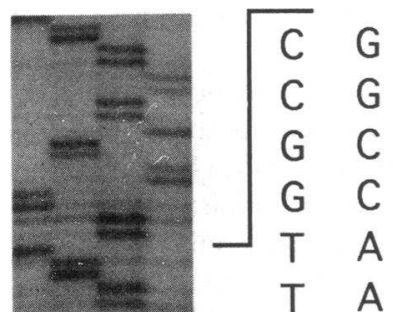

EXON 16
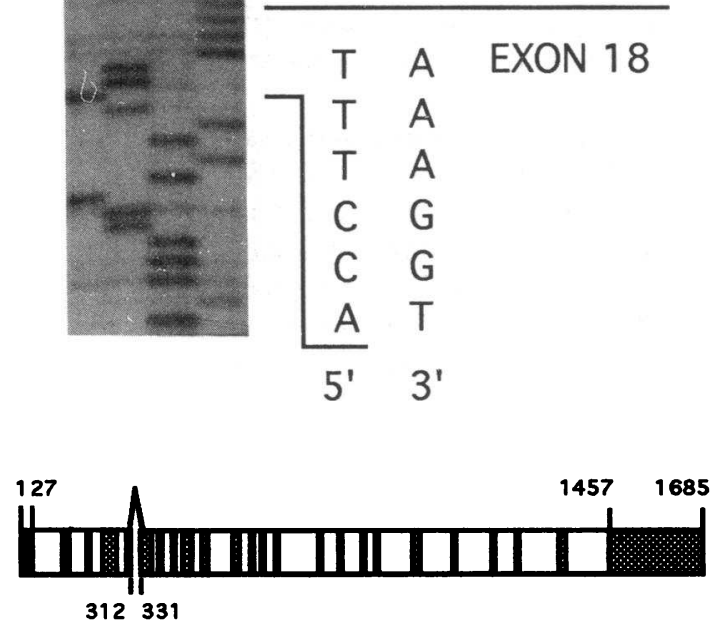

AC

A C G T 3 '

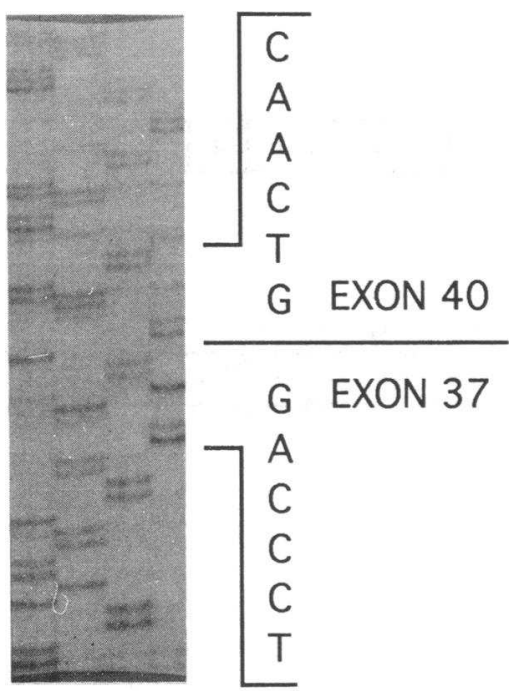

$5^{\prime}$

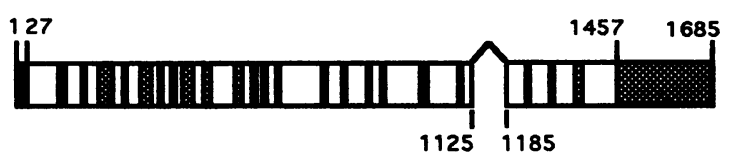

FP

Figure 4. Sequence analysis of the junction point of truncated $\alpha 5$ (IV) mRNA in lymphocytes from four AS patients with intragenic deletion. Beside each autoradiogram is shown the nucleotide sequence of the abnormal cDNA segment with the limits of exons. The four truncated transcripts are in frame. Below each sequence is shown the corresponding putative truncated $\alpha 5$ (IV) protein. The black box (amino acids 1-27) represents the signal peptide, the white pattern represents the collagenous Gly-X-Y repeat sequences, and shaded boxes represent interruptions in the collagenous sequences and NC domain. 
amino acids (Tyr-1126 to Pro-1263) in the collagenous domain of the $\alpha 5$ (IV) chain, with preservation of a repetitive though truncated Gly-X-Y sequence. With the same primers, amplification of patient F.P. RNA gave a 460 -bp product (Fig. $3 B$, lane 6 ) as compared to the 639-bp control. Sequence analysis (Fig. 4) showed splicing of exon 37 to exon 40 as expected from the size of the PCR product. The in frame transcript would code for a truncated $\alpha 5$ (IV) chain lacking 60 amino acids from Tyr-1126 to Pro-1184 in the collagenous domain.

\section{Determination of carrier status in females and origin of mutations}

Family members DNAs of five patients with deletions (four with altered size fragments) have been examined. In family N.P., densitometry analysis demonstrated that the asymptomatic mother's DNA displays the two copies of exon 1 (data not shown), suggesting a de novo mutation in the propositus. In family Y.T. (Fig. $5 \mathrm{~A}$ ), the patient's DNA lacks the 8- and 4.1-kb normal fragment and shows a 7-kb junction fragment, whereas the father and the maternal grandmother exhibit a normal pattern, demonstrating a new mutation in the affected mother, as the maternal grandfather was obviously clinically not affected. However, in this case, a germline mosaicism in the maternal grandmother cannot be completely excluded. In family M.B. (Fig. $5 B$ ), in the affected mother's DNA, both the normal 15-kb TaqI and the abnormal 11-kb TaqI fragments are present with HT14-2, whereas the junction fragment is not detected in the two sisters' DNA. Therefore, they could be assigned as noncarrier with certainty. In family F.P. (Fig. $5 C$ ), the mother's DNA displayed the same abnormal 14-kb fragment as her son's associated with the normal allele, whereas the maternal grandmother and the two maternal aunts displayed a normal pattern, indicating that a new mutation arose in the mother. In family A.C. (Fig. $5 \mathrm{D}$ ), the two affected brothers have an abnormal 11.7-kb fragment, while the three young sisters display a normal pattern and could be ascertained as noncarrier.

\section{Correlations between genotypes and phenotypes}

9 of the 14 deletions were found in patients presenting with juvenile AS demonstrated by proband and/or family disease
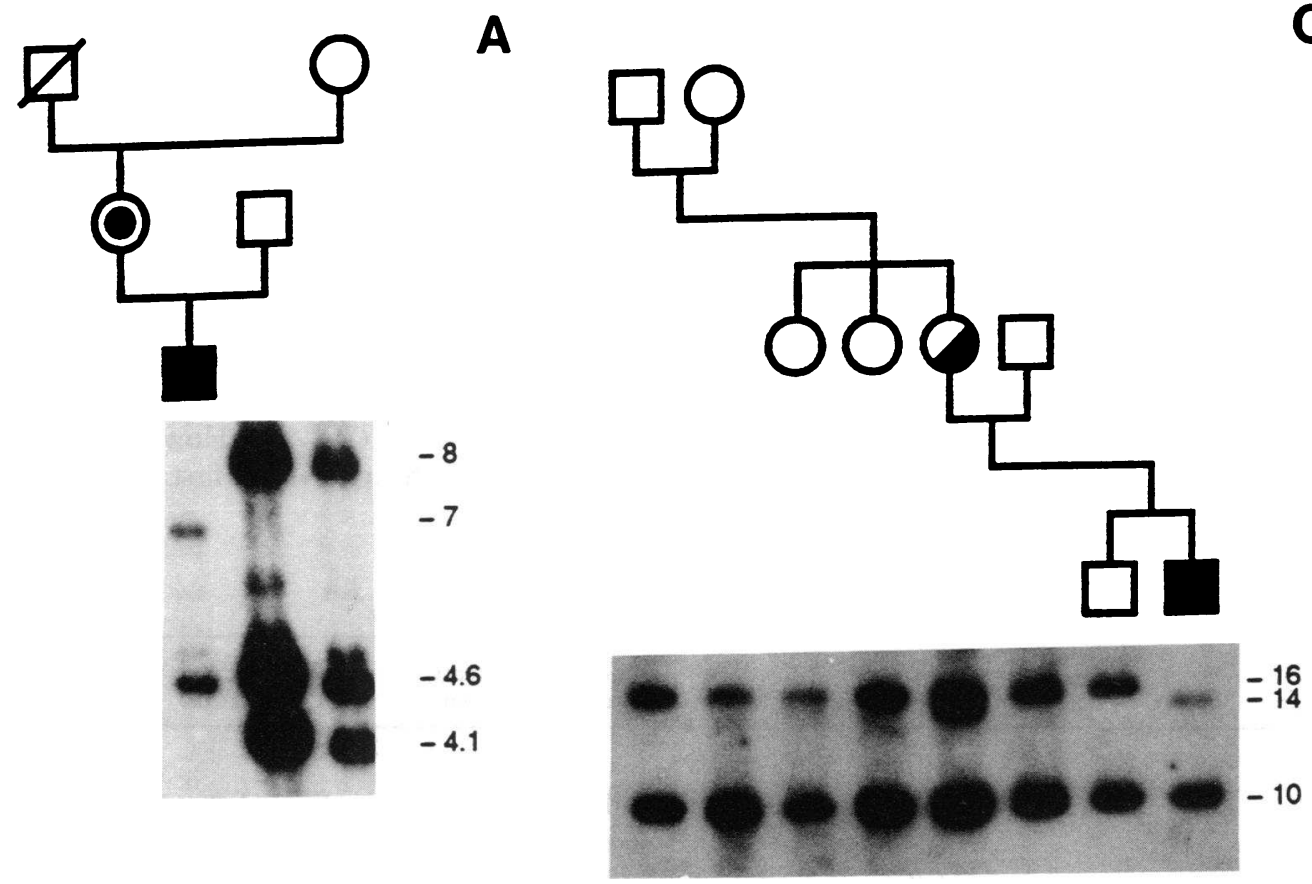

B
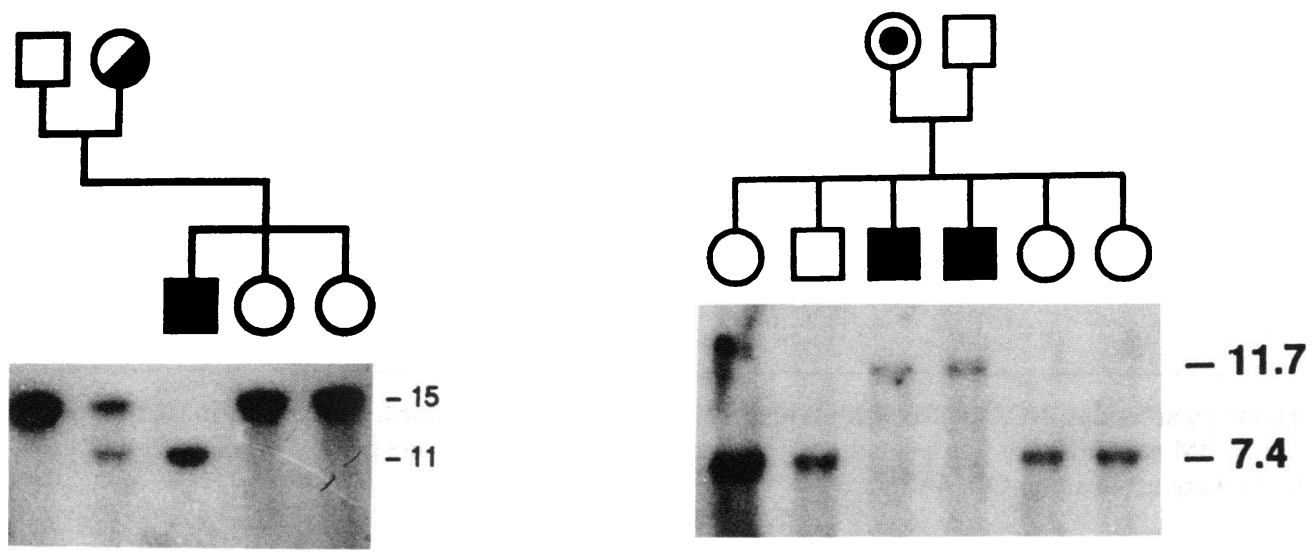

Figure 5. Southern blot analysis in four different AS kindreds. $(A)$ EcoRI digested DNA from a part of family Y.T. hybridized to HT14-3. The affected mother DNA was not available. $(B)$ TaqI digested DNA of kindred M.B. hybridized with probe HT14-2. (C) PstI digested DNA of kindred F.P. hybridized with probe PL-31. (D) MspI digested DNA of kindred A.C. hybridized with probe HT14-2. 
history. The five others were detected in 7-14-yr-old children whose AS could not be assigned to the juvenile- or adult-type categories. These children likely have juvenile-type AS as suggested by the early onset of renal and extrarenal symptoms. On the contrary, the point mutation with loss of the MspI site was found in a family with adult-type AS.

The clinical and histopathological findings of the $14 \mathrm{pa}-$ tients with deletions are detailed in Table III. While eight of them fulfilled at least three of the criteria considered for AS diagnostic, only two of these criteria were present in the other six patients. Two of these six patients had leiomyomatosis and cataracts which is not considered as a typical ocular lesion of AS. Hearing loss was absent in three children (S.D., J.C., F.P.) but they were only 4-8 yr old and their affected relatives were all females, but also in a 24-yr-old patient (F.D.) with leiomyomatosis, on hemodialysis for $9 \mathrm{yr}$. The GBM distribution of the $\alpha 3$ and $\alpha 4$ chains of type IV collagen was documented in four patients with deletions (patients F.D., N.P., J.C., F.P.). In the four patients, no GBM labeling was observed with anti$\alpha 3$ (IV) and anti- $\alpha 4$ (IV) antibodies. Tissue was not available for the patient with a point mutation.

All three patients (S.D., F.D., J.T.) who presented with diffuse esophageal leiomyomatosis associated with AS displayed deletion in the COL4A5 gene involving the $5^{\prime}$ part of the gene and extending beyond the 5 ' end of the gene.

No mutation has been detected in the four patients belonging to kindreds affected with progressive hereditary nephritis without extrarenal symptoms.

Among the 15 patients in which we found alterations of the COL4A5 gene, 9 had renal transplantation (patients Y.T., M.B., F.D., E.C., L.T., S.L., B.D., and B.F.). Only one of them (L.T.) developed posttransplant anti-GBM disease with circulating anti-GBM antibodies and crescentic glomerulonephritis. This patient was the one with the complete deletion of the COL $4 A 5$ gene.

\section{Discussion}

With standard gel electrophoresis of genomic DNA, using a set of cDNA probes covering all the COL $4 A 5 \mathrm{cDNA}$, we detected 15 different mutations, one single-base mutation (21) and 14 deletions, in 15 of 88 male AS patients. This finding corresponds to an overall deletion detection rate of $16 \%$. The percentage is higher than the 1 over 18 observed by Barker et al. (23) and by Smeets et al. (24), the 3/38 described by Boye et al. (25), the $2 / 16$ reported by Netzer et al. (26), and the 5/46 reported by Renieri et al. (27). However, this is the first report of a large series of AS patients tested with probes covering the entire COL4A5 cDNA, including the 5 ' end of the gene. This percentage of deletions found in this study is also higher than percentages reported in other hereditary disorders involving collagen genes, for example osteogenesis imperfecta (28). On the other hand, when the size of the COL4A5 gene $(\sim 250 \mathrm{~kb})$ is taken into account, the deletion rate does not appear to be excessively high in comparison with other $\mathrm{X}$-linked loci such as the 186-kb FVIII:C locus (6\% deletion rate), the $30-\mathrm{kb}$ ornithine transcarbamylase locus ( $10 \%$ deletions), the 44-kb HPRT locus ( $10 \%$ deletions), and the 2,000-kb Duchenne muscular dystrophy (DMD) locus (67\% deletions) (29). However, it is possible that some deletions in an X-linked AS population involve the very recently characterized COL $4 A 6$ gene, and not $C O L 4 A 5$. By contrast with the relative high deletion detection rate, we found only one single-base mutation at an MspI restriction site. This emphasizes the need for other methods to detect mutations involving one or a few nucleotides. The 14 detected deletions were not confined to any particular region of the COL4A5 gene. One deletion involves the entire gene, five involve the $5^{\prime}$ part of the gene with a $5^{\prime}$ breakpoint located upstream, and eight are intragenic deletions covering different parts of the collagenous domain of COL4A5. However, four breakpoints out of the 14 deletions involve the first intron (in

Table III. AS Patients with Deletions in the COL4A5 Gene

\begin{tabular}{|c|c|c|c|c|c|c|c|c|c|c|}
\hline & Patients & $\begin{array}{c}\text { AS } \\
\text { type }\end{array}$ & $\begin{array}{l}\text { Family } \\
\text { history }\end{array}$ & $\begin{array}{l}\text { Hearing } \\
\text { loss }\end{array}$ & $\begin{array}{l}\text { Ocular } \\
\text { lesions }\end{array}$ & $\begin{array}{l}\text { Thick } \\
\text { GBM }\end{array}$ & $\begin{array}{c}\text { GBM } \alpha 3(\mathrm{IV}) \\
\text { antigenicity }\end{array}$ & $\begin{array}{l}\text { Renal } \\
\text { graft }\end{array}$ & $\begin{array}{l}\text { Extension of the } \\
\text { COL4A5 deletion }\end{array}$ & $\begin{array}{l}\text { Reading } \\
\text { frame }\end{array}$ \\
\hline \multicolumn{11}{|l|}{$5^{\prime}$ end deletions } \\
\hline \multirow[t]{3}{*}{ With DL } & S.D. & NC & + & $-\neq$ & $+(\mathrm{C})$ & + & ND & - & ${ }^{8} \mathrm{E} 1$ to $\mathrm{E}$ ? & \\
\hline & F.D. & $\mathbf{J}$ & - & - & $+(C)$ & + & - & + & E1 & \\
\hline & J.T & NC & + & + & $+(\mathrm{C})$ & + & ND & - & E1 & \\
\hline \multirow[t]{3}{*}{ Without DL } & L.J. & $\mathbf{J}$ & + & + & - & ND & ND & $+^{*}$ & whole COL4A5 & \\
\hline & N.P. & $\mathrm{NC}$ & - & + & - & ND & - & - & E1 & \\
\hline & Y.T. & $\mathbf{J}$ & + & + & $+(\mathrm{L})$ & + & ND & + & $\mathrm{E} 1$ to $\mathrm{E}$ ? & \\
\hline \multirow[t]{8}{*}{ Intragenic deletions } & M.B. & $\mathbf{J}$ & + & + & $+(\mathrm{L} / \mathrm{M})$ & + & ND & + & $\mathrm{E} 4$ to $\mathrm{E} ?$ & $?$ \\
\hline & F.C. & NC & + & + & $+(\mathbf{M})$ & + & ND & - & $?$ & $?$ \\
\hline & A.C. & $\mathbf{J}$ & + & + & ND & ND & ND & + & E17 & IF \\
\hline & J.C. & $\mathrm{NC}$ & + & $-\neq$ & - & + & - & - & E2 to E36 & IF \\
\hline & B.F. & $\mathbf{J}$ & + & + & + & + & ND & + & $\mathrm{E} 3$ to $\mathrm{E} 40$ or $\mathrm{E} 41$ & FS \\
\hline & E.C. & $\mathbf{J}$ & + & + & + & ND & ND & + & E39 to E42 & PS \\
\hline & S.L. & $\mathbf{J}$ & + & + & - & ND & ND & + & E38 to E41 & IF \\
\hline & F.P. & $\mathrm{NC}$ & + & $-\neq$ & + & + & - & - & E38 to E39 & IF \\
\hline
\end{tabular}

(C), cataracts; (L), lenticonus; (M), perimacular lesions; NC, not classified; J, juvenile type; ND, not determined. E, exon; IF, in frame; FS, frameshift. * Patient L.T. developed anti-GBM nephritis after transplantation. ${ }^{\ddagger}$ Patients S.D., J.C., and F.P. are only 4-8 yr old. ${ }^{8}$ For 5' end deletions, the $5^{\prime}$ boundaries of the deletion are upstream to COL4A5. 
three cases, the $3^{\prime}$ breakpoint, in one case, the $5^{\prime}$ breakpoint). Further studies will clarify whether or not this is due to a deletion hot-spot, possibly related to the large size of this intron.

The extent of intragenic deletions has been estimated with a combination of genomic and CDNA probes. However, the precise limits of the deletions could not have been delineated confidently in all of them, by Southern analysis alone, because of the limited number of genomic probes and the insufficient data available on the restriction pattern in some COL $4 A 5$ regions (e.g., exon 37 ). In order to precisely determine whether each deletion breakpoint occurs within introns or exons, and whether a deletion disrupts the reading frame, we used a nested amplification approach to amplify $C O L 4 A 5$ illegitimate transcripts. It has been shown that any gene may be transcribed in any cell, whatever the tissue specificity, yielding a bona fide mature transcript (14). Illegitimate transcription offers the invaluable advantage of giving access to abnormal tissue-specific transcripts using easily available cells. We have already taken advantage of this ectopic transcription to characterize the point mutation detected by the loss of the MspI site in one patient of this series (21). But this technique is also a powerful method to characterize deletions, as shown in DMD (30).

In this study, we sequenced the junction point of truncated COL4A5 transcripts in PBL or EBV-established lymphoblasts from four patients with internal deletions of the $C O L 4 A 5$ gene. This permitted us to demonstrate that the four intragenic deletions that could be investigated at the mRNA level are intronintron mediated. Moreover we could ascertain the conservation of an open reading frame for all of them. By contrast, in two patients (B.F., E.C.) for whom lymphocyte RNA amplification was not available, a frameshift mRNA could be inferred from Southern blot analysis and genomic DNA exon amplification. It is noteworthy that both in-frame and frameshift deletions can lead to a similar severe phenotype, with extrarenal symptoms. Therefore, in opposition to DMD, no reading frame rule seems to exist in AS.

As the native $\alpha 5$ (IV) protein has not been isolated, we can only speculate on the structure of the mutated product. It must be absent for patient L.T. who has a complete deletion of the gene, and also for the five patients with deletions of the 5 ' part of the gene, involving the initiating codon and probably regulatory sequences. In patients with intragenic deletions, if the mRNA is stable enough to be translated, the protein product will be variably affected whether or not the open reading frame is maintained. The two out-of-frame deletions will result in severely altered proteins with truncated collagenous domains and absence of the $\mathrm{NCl}$ domain. The four in-frame deletions we have characterized at the mRNA level will be associated with truncated proteins lacking 18-1,055 amino acids in the collagenous domain, but with preservation of part of the Gly$\mathrm{X}-\mathrm{Y}$ repeat sequences and persistance of the noncollagenous $\mathrm{NCl}$ domain. Interestingly, deletion of as little as six Gly-X-Y triplets is sufficient to produce a severe juvenile phenotype with hearing loss ( patient A.C.). This finding suggests that even a short truncation of the collagenous structure of an $\alpha$ (IV) chain can impair the normal alignment and assembly of three $\alpha(I V)$ chains to form the triple helical molecule and then alter the supramolecular collagen IV network thus resulting in structural changes of the GBM. Another possibility is that abnormal chains are retained within the rough endoplasmic reticulum, as has been shown for mutated $\alpha 2$ (I) collagen chain in osteogene- sis imperfecta (31), and are not at all incorporated into a triplehelical molecule. Deletions, or major rearrangements of the COL4A5 gene, reported to date, were also observed in patients with juvenile AS (23-27, 32). On the contrary, the single-base mutation reported here was detected in a family with adult type AS, like other point mutations $(23,24,33)$ and a 10-bp insertion (34). However, single-base mutations may also be associated with severe forms of AS (34-38).

DNA analysis is helpful to correctly classify variants of AS on the basis of the molecular COL $4 A 5$ defects. We have shown that the syndrome characterized by DL, nerve deafness, cataract, and progressive nephritis also belongs to the AS spectrum (18). Furthermore, the three patients of this study and three additional patients referred to our laboratory because of the DL-AS association (39) have a deletion in the $5^{\prime}$ part of the gene extending beyond its $5^{\prime}$ end. In three of them, it has been shown that the deletion $5^{\prime}$ breakpoint lies within intron 2 of COL4A6 (13). This suggests that DL may be due to the alteration of COL4A6, which is highly expressed in esophagus (13) or of a second gene involved in smooth muscle cell proliferation and located in intron 2 of COL4A6. Interestingly, several of the deletions we identified result in phenotypes which do not even fulfill the currently used diagnostic criteria for AS (15). 6 among the 14 patients had only two criteria, whereas it has been suggested that at least three criteria are necessary for the diagnosis (15). For example, patient F.D. has a juvenile-type AS without hearing loss $9 \mathrm{yr}$ after he reached ESRF. This emphasizes the need for reclassification of AS, based on both clinical and molecular criteria.

2 of the 15 mutations reported in this study were detected in patients without any family history of AS. In one of them, the mother was proved to be noncarrier. Furthermore, in two other families, the mutation was shown to have occurred in the proband's mother. Two other de novo mutations have been described $(26,40)$. These findings confirm the previous estimation from Shaw et al. (41), based on the decreased reproductive fitness of affected males, that up to $18 \%$ of newborns with a gene for AS represent new mutations. They underline the fact that the diagnosis of AS, leading to molecular genetic investigations, has to be considered even in the absence of family history.

A puzzling immunohistochemical observation is the frequently abnormal distribution of the $\alpha 3$ and $\alpha 4$ chains of type IV collagen in X-linked AS patients $(4,5)$, presumed to have mutations in the COL4A5 gene and hence an abnormal $\alpha 5$ (IV) chain. Until now, no documented immunohistochemical studies have been reported in patients with proven $C O L 4 A 5$ mutations. In this study, the immunohistochemical analysis of the GBM distribution of collagen IV chains revealed the absence of the $\alpha 3$ and $\alpha 4$ chain antigens in four patients with COL4A5 deletions. This finding shows for the first time that structural changes in the $\alpha 5$ (IV) chain can impair the incorporation of $\alpha 3$ (IV) and $\alpha 4$ (IV) chains within the type IV collagen network, a hypothesis proposed by Kashtan et al. (42). About $1-5 \%$ of transplanted AS male patients develop antiGBM antibodies leading to severe crescentic glomerulonephritis and subsequent graft loss. The alloimmunization of AS patients has been considered as triggered by the introduction of GBM containing antigenic epitopes, located in the NC1 domain of type IV collagen, that are absent in the recipient (43, 44 ). In our series, only patient L.T. who has a complete dele- 
tion of COL4A5 developed anti-GBM nephritis. One other complete deletion of COL4A5 have been reported to date (26) and is also associated with anti-GBM nephritis. However, other molecular lesions such as deletions involving exons coding for the $\mathrm{NCl}$ domain of $\alpha 5$ (IV) and a point mutation affecting the $3^{\prime}$ splicing site of exon 38 were associated with the same complication $(24,33,37)$. Conversely, in our series, six transplanted patients ( Table III) with major deletions, some of them presumably leading to the complete absence of the $\alpha 5$ (IV) chain, did not develop anti-GBM antibodies. It clearly shows that other factors, in addition to the genetic defect, are implicated in the occurrence of this allo-immunization.

Correct identification of carrier females is crucial for genetic counselling. We could detect altered-size fragments (junction fragments) in 8 of the 14 patients with deletion by standard Southern blotting, and thus we obtained a simple test to identify carrier females, as shown in four of these families (Fig. 5). However, detection of carrier status is a difficult task in half of the cases since it has to be based on the hazardous interpretation of gene dosage. To overcome this problem, the detection of COL4A5 transcripts from PBL RNA could be used for rapid detection of female deletion carriers, as shown for the DMD gene (45). Furthermore, this approach could make point mutation screening a practical proposition.

\section{Acknowledgments}

We thank Drs. B. Boudaillez, A. Bourdais, M. Buemi, P. Cochat, R. Genin, M. Guillot, C. Huet, A. Joannard, P. Lebon, Y. Lemeur, C. Loirat, M. Mathieu, A. Nivelon, P. Le Pogamp, M. Quillard, J. P. Rivière, B. Roussel, P. Simon, and J. D. Sraer; and D. Hillaire and C. Montchamp-Moreau for referring the patients; Drs. P. Birembaut, N. Bove, F. Buzelin for sending renal specimens; M. Kleppel and J. Wieslander for giving us the anti- $\alpha 3$ and anti- $\alpha 4$ (IV) antibodies; and Dr. C. Kashtan for helpful discussion. We are indebted to Genethon (Evry, France) for lymphoblastoid cell culture.

This work was supported by INSERM, Assistance Publique Hôpitaux de Paris, the Association Française contre les Myopathies, the Caisse Nationale de l'Assurance Maladie des Travailleurs Salariés, and the Association pour la Recherche sur le Cancer.

\section{References}

1. Alport, A. C. 1927. Hereditary familial congenital haemorrhagic nephritis. Br. Med. J. (Clin. Res.). 1:504-506.

2. Atkin, C. L., M. C. Gregory, and W. A. Border. 1988. Alport syndrome. In Diseases of the Kidney. 4th edition. R. W. Schrier and C. W. Gottschalk, editors. Little Brown \& Co., Boston. 617-641.

3. Feingold, J., E. Bois, A. Chompret, M. Broyer, M. C. Gubler, and J. P. Grünfeld. 1985. Genetic heterogeneity of Alport syndrome. Kidney Int. 27:672677.

4. Gubler, M. C., C. Antignac, G. Deschênes, B. Knebelmann, M. C. HorsCayla, J. P. Grünfeld, M. Broyer, and R. Habib. 1993. Genetic, clinical and morphologic heterogeneity in Alport's syndrome. Adv. Nephrol. 22:15-35.

5. Kashtan, C., A. J. Fish, M. Kleppel, K. Yoshioka, and A. F. Michael. 1986. Nephritogenic antigen determinants in epidermal and renal basement membranes of kindreds with Alport-type familial nephritis. J. Clin. Invest. 78:10351044.

6. Soininen, R., M. Huotari, S. L. Hostikka, D. J. Prockop, and K. Tryggvason. 1988. The structural genes for $\alpha 1$ and $\alpha 2$ chains of human type IV collagen are divergently encoded on opposite DNA strands and have an overlapping promoter region. J. Biol. Chem. 263:17217-17220.

7. Butkowski, R. J., J. P. M. Langeveld, J. Wieslander, J. Hamilton, and B. G. Hudson. 1987. Localization of the Goodpasture epitope to a novel chain of basement membrane collagen. J. Biol. Chem. 262:7874-7877.

8. Gunwar, S., J. Saus, M. E. Noelken, and B. G. Hudson. 1990. Glomerular basement membrane: identification of a fourth chain, $\alpha 4$, of type IV collagen. $J$. Biol. Chem. 265:5466-5469.
9. Mariyama, M., K. Zheng, T. L. Yang-Feng, and S. T. Reeders. 1992. Colocalization of the genes for the $\alpha 3$ (IV) and $\alpha 4$ (IV) chains of type IV collagen to chromosome 2 bands q35-q37. Genomics. 13:809-813.

10. Hostikka, S. L., R. L. Eddy, M. G. Byers, M. Hoyhtya, T. B. Shows, and K. Tryggvason. 1990. Identification of a distinct type IV collagen alpha chain with restricted kidney distribution and assignment of its gene to the locus of X-linked Alport syndrome. Proc. Natl. Acad. Sci. USA. 87:1606-1610.

11. Atkin, C. L., S. J. Hasstedt, L. Menlove, L. Cannon, N. Kirschner, C. Schwartz, K. Nguyen, and M. H. Skolnick. 1988. Mapping of Alport syndrome to the long arm of the X chromosome. Am. J. Hum. Genet. 42:249-255.

12. Tryggvason, K., J. Zhou, S. L. Hostikka, and T. B. Shows. 1993. Molecular genetics of Alport syndrome. Kidney Int. 43:38-44.

13. Zhou, J., T. Mochizuki, H. Smeets, C. Antignac, P. Laurila, A. de Paepe, K. Tryggvason, and S. T. Reeders. 1993. Deletion of the paired $\alpha 5$ (IV) and $\alpha 6$ (IV) collagen genes in an inherited smooth muscle tumor. Science (Wash. DC). 261:1167-1169.

14. Chelly, J., J. P. Concordet, J. C. Kaplan, and A. Kahn. 1989. Illegitimate transcription: Transcription of any gene in any cell type. Proc. Natl. Acad. Sci. USA 86:2617-2621.

15. Flinter, A. F., J. S. Cameron, C. Chantler, I. Houston, and M. Bobrow. 1988. Genetics of classical Alport's syndrome. Lancet. ii:1005-1007.

16. Kleppel, M. M., P. A. Santi, J. D. Cameron, J. Wieslander, and A. F. Michael. 1989. Human tissue distribution of novel basement membrane collagen. Am. J. Pathol. 134:813-825.

17. Butkowski, R. J., J. Wieslander, M. M. Kleppel, A. F. Michael, and A. J. Fish. 1989. Basement membrane collagen in the kidney: regional localization of novel chains related to collagen IV. Kidney Int. 35:1 195-1202.

18. Antignac, C., J. Zhou, M. Sanak, P. Cochat, B. Roussel, G. Deschênes, F. Gros, B. Knebelmann, M. C. Hors-Cayla, K. Tryggvason, et al. 1992. Alport syndrome and diffuse esophageal leiomyomatosis: deletions in the $5^{\prime}$ end of the COL4A5 collagen gene. Kidney Int. 42:1178-1183.

19. Zhou, J., S. L. Hostikka, L. T. Chow, and K. Tryggvason. 1991. Characterization of the 3' half of the human type IV collagen $\alpha 5$ gene that is affected in the Alport syndrome. Genomics. 9:1-9.

20. Chirgwin, J. M., A. E. Przybyla, R. J. Mac Donald, and W. J. Rulter. 1979. Isolation of biologically active ribonucleic acids from sources enriched in ribonuclease. Biochemistry. 18:5294-5299.

21. Knebelmann, B., G. Deschênes, F. Gros, M. C. Hors, J. P. Grünfeld, K Tryggvason, M. C. Gubler, and C. Antignac. 1992. Substitution of arginine for glycine-325 in the collagen $\alpha 5$ (IV) chain associated with X-linked Alport syndrome: characterization of the mutation by direct sequencing of PCR-amplified lymphoblast cDNA fragments. Am. J. Hum. Genet. 51:135-142.

22. M'rad, R., M. Sanak, G. Deschênes, J. Zhou, C. Bonaiti-Pellie, L. Holvoet-Vermaut, M. C. Gubler, M. Broyer, J. P. Grünfeld, K. Tryggvason, et al. 1992. Alport syndrome: a genetic study of 31 families. Hum Genet. 90:420-426.

23. Barker, D. F., S. L. Hostikka, J. Zhou, L. T. Chow, A. R. Oliphant, S. C. Gerken, M. C. Gregory, M. H. Skolnick, C. L. Atkin, and K. Tryggvason. 1990. Identification of mutations in the COL4A5 collagen gene in Alport syndrome. Science (Wash. DC). 247:1224-1227.

24. Smeets, H. J. M., J. J. Melenhorst, H. H. Lemmink, C. H. Schroder, M. R. Nelen, J. Zhou, S. L. Hostikka, K. Tryggvason, H. H. Ropers, M. C. E. Jansweijer, et al. 1992. Different mutations in the COL4A5 collagen gene in two patients with different features of Alport syndrome. Kidney. Int. 42:83-88.

25. Boye, E., D. Vetrie, F. Flinter, B. Buckle, T. Pihlajaniemi, E. R. Hamalainen, J. C. Myers, M. Bobrow, and A. Harris. 1991. Major rearrangements in the $\alpha 5$ (IV) collagen gene in three patients with Alport syndrome. Genomics. 11:1125-1132.

26. Netzer, K. O., L. Renders, J. Zhou, O. Pullig, K. Tryggvason, and M. Weber. 1992. Deletions of the COL4A5 gene in patients with Alport syndrome. Kidney Int. 42:1336-1344.

27. Renieri, A., M. Seri, L. Galli, and M. De Marchi. 1993. Screening of mutations in the COL4A5 gene: report of the Italian Multicenter Study. In Proceedings of the Second International Workshop on Alport Syndrome. 23.

28. Kuivaniemi, H., G. Tromp, and D. J. Prockop. 1991. Mutations in collagen genes: cause of rare and common diseases in humans. FASEB J. 5:20522060.

29. Darras, B. T., P. Blattner, J. F. Harper, A. J. Spiro, S. Alter, and U. Francke. 1988. Intragenic deletions in 21 Duchenne muscular dystrophy (DMD)/Becker muscular dystrophy (BMD) families studied with the dystrophin cDNA: location of breakpoints on $\mathrm{Hind}$ III and $\mathrm{Bg} / \mathrm{II}$ exon-containing fragment maps, meiotic and mitotic origin of the mutations. Am. J. Hum. Genet. 43:620-629.

30. Roberts, R. G., T. F. M. Barby, E. Manners, M. Bobrow, and D. R Bentley. 1991. Direct detection of dystrophin gene rearrangements by analysis of dystrophin mRNA in peripheral blood lymphocytes. Am. J. Hum. Genet. 49:298-310.

31. Willing, M. C., D. H. Cohn, B. Starman, K. A. Holbrook, C. R. Greenberg, and P. H. Byers. 1988. Heterozygosity for a large deletion in the $\alpha 2(\mathrm{I})$ collagen gene has a dramatic effect on type I collagen secretion and produces perinatal lethal osteogenesis imperfecta. J. Biol. Chem. 263:8398-8404. 
32. Kashtan, C. E., A. F. Michael, and M. M. Kleppel. 1991. Alport syndrome. Association of deletions in the COL4A5 gene with post-transplant antiGBM nephritis (GN). J. Am. Soc. Nephrol. 2:256. (Abstr.)

33. Zhou, J., M. C. Gregory, J. M. Hertz, C. F. Barker, C. Atkin, E. S. Spencer, and $\mathrm{K}$. Tryggvason. 1993. Mutations in the codon for a conserved arginine-1563 in the COL4A5 collagen gene in Alport syndrome. Kidney Int. 43:722-729.

34. Lemmink, H. H., C. H. Schröder, H. G. Brunner, M. R. Nelen, J. Zhou, K. Tryggvason, W. A. G. Haasgsma-Schouten, A. P. Roodvoets, W. Rasher, B. A. van Oost, et al. 1993. Identification of four novel mutations in the COL4A5 gene of patients with Alport syndrome. Genomics. 17:485-489.

35. Zhou, J., J. M. Hertz, A. Leinonen, and K. Tryggvason. 1992. Complete amino acid sequence of the human $\alpha 5$ (IV) collagen chain and identification of a single-base mutation in exon- 23 converting glycine-521 in the collagenous domain to cysteine in an Alport syndrome patient. J. Biol. Chem. 267:1247512481.

36. Zhou, J., J. M. Hertz, and K. Tryggvason. 1992. Mutation in the $\alpha 5$ (IV) collagen chain in juvenile-onset Alport syndrome without hearing loss or ocular lesions: detection by denaturing gradient gel electrophoresis of a PCR product. Am. J. Hum. Genet. 50:1291-1300.

37. Netzer, K. O., O. Pullig, U. Frei, J. Zhou, K. Tryggvason, and M. Weber. 1993. COL4A5 splice site mutation and $\alpha 5$ (IV) collagen mRNA in Alport syndrome. Kidney Int. 43:486-492.

38. Nomura, S., G. Osawa, T. Sai, T. Harana, and K. Harano. 1993. A splicing mutation in the $\alpha 5$ (IV) collagen gene of a family with Alport's syndrome. Kidney Int. 43:1116-1124.
39. Antignac, C., F. Gros, C. Geffriaud, C. Kashtan, W. Proesmans, K. Tryggvason, and M. C. Gubler. 1992. Alport syndrome and diffuse esophageal leiomyomatosis: deletions in the 5 ' end and upstream region of the COL4A5 collagen gene. Am. J. Hum. Genet. 51:A7.

40. Renieri, A., M. Seri, J. C. Myers, T. Pihlajaniemi, L. Massella, G. Rizzoni, and M. De Marchi. 1992. De novo mutation in the COL4A5 gene converting glycine-325 to glutamic acid in Alport syndrome. Hum. Mol. Genet. 1:127-129.

41. Shaw, R. F., and R. J. Kallen. 1976. Population genetics of Alport's syndrome. Hypothesis of abnormal segregation and the necessary existence of mutation. Nephron. 22:15-35.

42. Kashtan, C. E., M. M. Kleppel, R. J. Butkowski, A. F. Michael, and A. J. Fish. 1990. Alport syndrome, basement membranes and collagen. Pediatr. Nephrol. 4:523-532.

43. Kashtan, C. E., R. J. Butkowski, M. M. Kleppel, M. R. First, and A. F. Michael. 1990. Post-transplant anti-glomerular basement membrane nephritis in related males with Alport syndrome. J. Lab. Clin. Med. 116:508-515.

44. Hudson, B. G., R. Kalluri, S. Gunwar, M. Weber, F. Ballester, J. K. Hudson, M. E. Noelken, M. Sarras, W. R. Richardson, J. Saus, et al. 1992. The pathogenesis of Alport syndrome involves type-IV collagen molecules containing the $\alpha 3$ (IV) chain: evidence from anti-GBM nephritis after renal transplantation. Kidney Int. 42:179-187.

45. Roberts, R. G., D. R. Bentley, T. F. Barby, E. Manners, and M. Bobrow. 1990. Direct diagnosis of carriers of Duchenne and Becker muscular dystrophy by amplification of lymphocyte RNA. Lancet. 336:1523-1526. 